\title{
ANALISIS TINGKAT KEMANDIRIAN BELAJAR SISWA PADA MATA PELAJARAN FISIKA KELAS XII MAN 1 BATANG HARI
}

\author{
Rizki Intan Sari \\ Program Studi Pendidikan Fisika, Universitas Jambi \\ Email : rizkiintan046@gmail.com
}

DOI: http://dx.doi.org/10.29303/jpft.v5i2.1436

\begin{abstract}
This study aims to analyze the attitude of learning independence against learning physics for students of class XII MIA MAN 1 Batang Hari. This research uses quantitative research methods with descriptive statistical analysis techniques. The research sample uses a sampling technique that is total sampling. Total sampling is a sampling technique where the number of samples is equal to the population. The technique of collecting data is by submitting an instrument consisting of a questionnaire to a predetermined research sample. The results of this study indicate that the assessment of student independence is in the good category but some are not good.
\end{abstract}

Keywords: Education; Attitude; Independence; Physics

\section{PENDAHULUAN}

Fisika adalah cabang IPA yang mendasari perkembangan teknologi maju dan konsep hidup harmonis dengan alam (Sarah, 2019). Fisika dalam kajiannya memiliki konsep-konsep yang bersifat nyata dan juga bersifat abstrak. Konsep-konsep sains khususnya fisika memiliki peranan penting dalam perkembangan teknologi di era global (Hidayat, 2019). Teknologi yang dikembangkan dapat memberikan manfaat serta pengaruh yang besar bagi kehidupan manusia. Hal itu tidak akan terjadi tanpa memahami ilmu sains melalui proses pembelajaran.

Dalam proses pembelajaran diperlukan unsur yang penting untuk mencapai tujuan yang diinginkan. Proses pembelajaran pada dasarnya merupakan suatu proses interaksi belajar antara guru dengan peserta didik. Interaksi belajar mengajar ialah hubungan timbal balik antara guru (pengajar) dan anak (murid) yang harus menunjukkan adanya hubungan yang bersifat edukatif (mendidik) (Inah, 2015). Intraksi antara guru dan siswa dapat ditimbulkan melalui penyampaian materi pembelajaran di dalam kelas yang sekaligus terjadi komunikasi diantara guru dan peserta didik. Guru bukan hanya menjalankan tugas untuk menyampaikan materi pembelajaran tapi juga memfasilitasi terjadinya intraksi dan relasi di antara sesama siswa dan antara guru dan siswa (Iriantara, 2014). Hal inilah yang akan memungkinkan guru dapat mengenali karakteristik, potensi serta kemampuan yang dimiliki oleh peserta didik.

Dalam proses pembelajaran, sikap peserta didik sangatlah penting. Sikap sangat penting dalam proses berlangsungnya pembelajaran (Astalini, 2019). Sikap peserta didik berperan sebagai penunjang dalam mencapai tujuan pembelajaran. Sikap tersebut dapat berbentuk sikap positif ataupun sikap negatif yang dapat mempengaruhi hasil belajar peserta didik. Dengan kata lain, bahwa siswa yang mempunyai sikap positif dalam pelajaran tertentu cenderung lebih rajin dalam belajar sehingga mencapai hasil belajar yang lebih memuaskan. Sedangkan siswa yang mempunyai sikap negatif dalam pelajaran, maka dia tidak akan bersemangat belajar sehingga hasil yang didapatkannya kurang maksimal. Sikap positif diartikan sebagai sikap yang dapat mendukung peserta didik dalam mempelajari pelajaran fisika, seperti menyenangi pelajaran tersebut dan sikap yang negatif merupakan dianggap sebagai 
sikap yang menghambat dalam mempelajari fisika. Untuk itu diperlukan pendidikan karakter dalam kegiatan proses belajar mengajar.

Pendidikan memiliki peran dalam pengembangan karakter melalui pendidikan karakter (Supriyanto \& Wahyudi, 2017). Pendidikan karakter sangat penting sekali untuk diterapkan dalam diri peserta didik. Penerapannya bisa diterapkan dalam lingkungan sekolah, lingkungan keluarga, atau bahkan lingkungan masyarakat. Hal ini dikarenakan tidak hanya guru yang dapat membantu menerapkan nilai karakter tersebut, tetapi orangtua, masyarakat, dan teman-teman di sekeliling kita juga bisa membantu menerapkan nilai karakter tersebut.

Salah satu pendidikan karakter yang harus diterapkan yaitu kemandirian. Pada saat ini nilai kemandirian merupakan salah satu nilai karakter yang perlu mendapatkan perhatian khusus. Kemandirian belajar masih menjadi fokus permasalahan dalam dunia pendidikan yang cukup memprihatinkan. Hasil penelitian Nahdliyati et al. (2016), Siswanto (2016) dan Taupik et al. (2017) menunjukkan kemandirian belajar siswa dapat dikatakan dalam kategori rendah. Faktanya individu yang tidak mempunyai kemandirian pasti tidak akan bisa berdiri sendiri dan tidak akan timbul suatu kepercayaan diri dalam menghadapi kehidupan khususnya dalam kehidupan di dunia pendidikan.

Kata mandiri mengandung arti tidak bergantung kepada orang lain, bebas, dan dapat melakukan sendiri (Rusman, 2014). Mandiri yang dimaksud adalah kemandirian belajar siswa. Kemandirian belajar diartikan sebagai sifat serta kemampuan yang dimiliki siswa untuk melakukan kegiatan belajar aktif, yang didorong oleh motif untuk menguasai sesuatu kompetensi, dan dibangun dengan bekal pengetahuan atau kompetensi yang telah dimiliki (Aini, 2012). Kemandiran belajar adalah sikap yang harus dilakukan siswa pada saat belajar secara mandiri, siswa memiliki inisiatif sendiri sesuai dengan kebutuhan dari siswa itu sendiri. Kemandirian selalu membantu proses belajar dengan mengaktifkan pengetahuan, pemantapan dan pengamanan yang telah dipelajari, maupun memberikan motivasi sehubungan dengan kesediaan belajar (Holstein, 2000).

Sikap kemandirian belajar pada diri siswa melalui pendidikan karakter diyakini akan berdampak pada hasil belajar yang akan diraih siswa, khusunya hasil belajar pada ranah kognitif yang dikenal dengan istilah prestasi belajar. Siswa dapat dikatakan memiliki kemandirian belajar jika memilki ciri-ciri diantaranya: mampu berpikir kritis, kreatif dan inovatif, tidak mudah terpengaruh pendapat orang lain, tidak merasa rendah diri, terus bekerja dengan penuh ketekunan dan kedisipilinan (Lestari, 2015). Babari (2002) membagi ciri-ciri kemandirian dalam lima jenis, yaitu: 1) Percaya diri; 2) Mampu bekerja sendiri; 3) Menguasai keahlian dan keterampilan yang sesuai dengan kerjanya; 4) Menghargai waktu; dan 5) Bertanggung jawab.

Implikasi sosial dari pembelajaran fisika memperlihatkan bagaimana pengaruh atau dampak dari ilmu fisika dalam kehidupan sosial. Manfaat sosial yang diperoleh sebagai akibat perkembangan sains dan teknologi. Dalam pembelajaran disekolah, implikasi sosial dari fisika dapat dilihat dari tingkat kemandirian siswa dalam belajar. Bentuk kemandirian siswa dapat dilihat dari pengerjaan PR maupun tugas yang diberikan oleh guru serta bagaimana siswa tidak bergantung pada orang lain dan meyakini kemampuannya sendiri.

Berdasarkan hasil observasi awal, Siswa di MAN 1 kabupaten Batanghari 
masih ada sebagian siswa yang kurang tertarik mempelajari fisika karena memandang fisika itu sulit. Dapat dilihat dari hasil pengisian angket bahwa sebagian siswa masih ada yang mencontek saat ujian dan tidak tepat waktu dalam mengerjakan tugas atau PR. Hal itulah yang menyebabkan sikap kemandirian siswa masih kurang tertanam dalam diri siswa itu sendiri. Masalah-masalah tersebut dapat menjadi faktor penyebab rendahnya kualitas pendidikan.

Oleh karena itu, penting untuk dianalisis kemandirian belajar siswa pada mata pelajaran Fisika agar diketahui secara empiris mengenai kemandirian belajar siswa yang kemudian dengan mudah menentukan langkah untuk mengatasinya dalam kegiatan proses belajar mengajar untuk menumbuhkan sikap kemandirian belajar siswa di kelas terhadap mata pelajaran fisika. Sehingga dilakukanlah penelitian ini yang bertujuan untuk menganalisis sikap kemandirian siswa terhadap pembelajaran Fisika di MAN 1 Batang Hari.

\section{METODE PENELITIAN}

Penelitian ini merupakan penelitian kuantitatif deskriptif. Peneliti mengumpulkan fakta tentang sikap kemandirian belajar siswa pada pembelajaran fisika dengan menggunakan angket kemandirian belajar fisika. Sehingga, diperoleh data kuantitatif yang perlu dianalisis untuk menghasilkan informasi yang akurat. Hubungan antara peneliti dan siswa kelas XII MIA di MAN Batang Hari bersifat independen. Populasi dalam penelitian ini adalah seluruh siswa kelas XII MIA di MAN 1 Batang Hari, sebagaimana akan dijelaskan pada tabel 1. Peneliti menggunakan teknik pengambilan sampel yaitu total sampling. Peneliti menggunakan total sampling karena peneliti ingin hasil penelitian berlaku untuk populasi yaitu siswa kelas XII MIA di MAN 1 Batang Hari.

Tabel 1. Populasi Siswa Kelas XII MIA di MAN 1 Batang Hari

\begin{tabular}{lll}
\hline Kelas & Nama Kelas & $\begin{array}{l}\text { Jumlah } \\
\text { Siswa }\end{array}$ \\
\hline XII MIA & XII MIA 1 & 22 \\
\cline { 2 - 3 } & XII MIA 2 & 21 \\
\hline Total & & 43 Siswa
\end{tabular}

(Sumber: Data Primer yang diperoleh)

\section{Teknik Pengumpulan Data}

Data yang diperlukan adalah data primer. Data primer yang diperoleh berupa data penerapan nilai karakter kemandirian belajar siswa pada pembelajaran fisika yang diambil dengan menggunakan instrumen angket. Angket adalah cara pengumpulan data dengan menggunakan daftar isian atau daftar pertanyaan tertulis yang telah disiapkan dan disusun sedemikian rupa yang digunakan untuk memperoleh informasi dari responden tentang pribadinya atau hal-hal lain yang diketahuinya (Permana, 2014). Jenis angket yang digunakan yaitu angket tertutup berupa angket sikap kemandirian belajar siswa pada pembelajaran fisika. Angket sikap ini dilakukan dengan menggunakan pengukuran Skala Likert. Skala Likert digunakan untuk mengukur sikap, pendapat, dan persepsi seseorang atau sekelompok orang tentang fenomena sosial (Sugiyono, 2016). Angket tersebut terdiri dari 30 item pernyataan positif tentang kemandirian belajar siswa pada pembelajaran fisika. Penilaian skala Likert ini menggunakan 4 indikator skala yaitu sangat setuju (SS), setuju (S), tidak setuju (TS), dan sangat tidak setuju (STS). Untuk pernyataan yang bernilai positif $(+)$ pengukuran dimulai dari nilai 4, 3, 2, dan 1 . Pada skala sangat setuju (SS) memiliki skor 4, setuju (S) memiliki skor 3, tidak setuju (TS) memiliki skor 2, dan sangat tidak setuju (STS) memiliki skor 1. Sedangkan 
sebaliknya untuk pernyataan yang bernilai negatif (-) pengukurannya dimulai dari nilai 4, 3, 2, dan 1 pada skala sangat tidak setuju (STS). Dimana sangat tidak setuju (STS) memiliki skor 4, tidak setuju (TS) memiliki skor 3, setuju (S) memiliki skor 2, dan sangat setuju (SS) memiliki skor 1.

\section{Teknik Analisis Data}

Setelah data dari seluruh responden terkumpul peneliti melakukan kegiatan dalam analisis data, sebagai berikut:

1. Mentabulasi Data

Setelah data terkumpul, peneliti akan mentabulasi data berdasarkan variabel yang diteliti.

Tabel 2. Tabulasi Data

\begin{tabular}{ll}
\hline Alternatif Respon & Skor \\
\hline Sangat Tidak Setuju & 1 \\
\hline Tidak Setuju & 2 \\
\hline Setuju & 3 \\
\hline Sangat Setuju & 4 \\
\hline
\end{tabular}

\section{Menganalisis Data}

Teknik analisis data pada penelitian kuantitatif ini menggunakan statistik deskriptif. Statistik deskriptif digunakan untuk penyajian data hasil angket. Analisis statistik deskriptif diperlukan untuk mengetahui bagaimana hasil sebaran data penelitian yang dijaring melalui angket (Burhan, 2013). Analisis statistik deskriptif dilakukan dengan cara menghitung mean, modus, median, range nilai minimum, nilai maksimum, standar deviasi dan presentasi mengenai hasil angket karakter kemandirian belajar yang diberikan kepada siswa.

Untuk menentukan jarak interval digunakan persamaan:

$$
i=\frac{\text { skor tertinggi }- \text { skor terendah }}{\text { jumlah kelas interval }}
$$

Keterangan:

$\mathrm{i}=$ jarak interval
Sehingga dapat diperoleh kategori kemandiran belajar siswa pada pembelajaran fisika pada Tabel 3 berikut.

Tabel 3. Kategori Kemandirian Belajar

\begin{tabular}{lll}
\hline No & Interval skor & Kategori \\
\hline 1 & $45-56,5$ & Sangat Tidak Setuju \\
\hline 2 & $56,6-68$ & Tidak Setuju \\
\hline 3 & $69-79,5$ & Setuju \\
\hline 4 & $79,6-91$ & Sangat Setuju \\
\hline
\end{tabular}

Hasil dari data angket diolah menggunakan aplikasi SPSS Statistics 23. Pengolahan ini bertujuan untuk melihat sikap tentang kemandirian belajar siswa MAN 1 Batang Hari berdasarkan indikator sikap yang telah ditentukan.

\section{HASIL DAN PEMBAHASAN}

Penelitian ini bertujuan untuk menganalisis sikap kemandirian belajar pada pembelajaran Fisika siswa kelas XII MIA di MAN 1 Batang Hari. Penelitian ini dilakukan dengan cara menyebarkan angket kepada peserta didik. Angket yang digunakan dalam penelitian ini merupakan angket karakter "kemandirian belajar" yang diadopsi dari skripsi Daeli (2018) yang telah teruji validasi dan reliabilitas, dimana angket tersebut terdiri dari 30 item pernyataan positif tentang kemandirian belajar siswa pada pembelajaran Fisika. Jumlah sampel dalam penelitian ini adalah sebanyak 43 sampel, dimana dari kelas XII MIA 1 dengan jumlah siswa 22 siswa dan kelas XII MIA 2 dengan jumlah siswa 21 siswa.

Hasil data ini didapatkan dari penyebaran angket, angket yang digunakan berupa angket kemandirian belajar siswa terhadap pelajaran Fisika. Hasil data angket kemandirian dibawah ini ditampilkan pada analisis data yang dianalisis menggunakan aplikasi SPSS. Penilaian berdasarkan interval yang memiliki skala 4 yaitu sangat setuju, setuju, tidak setuju, dan sangat tidak setuju. Peniliaian kategori sikap ini 
berdasarkan frekuensi dan persentase dari seluruh siswa kelas XII MIA yang memilih skala sikap. Hasil dari penilaian ini berdasarkan jumlah dari seluruh siswa yang memilih skala sikap tersebut yang menghasilkan mean, modus, median, dan standar deviasi.

Tabel 4. Analisis Kemandirian Belajar Siswa Kelas XII MIA 1

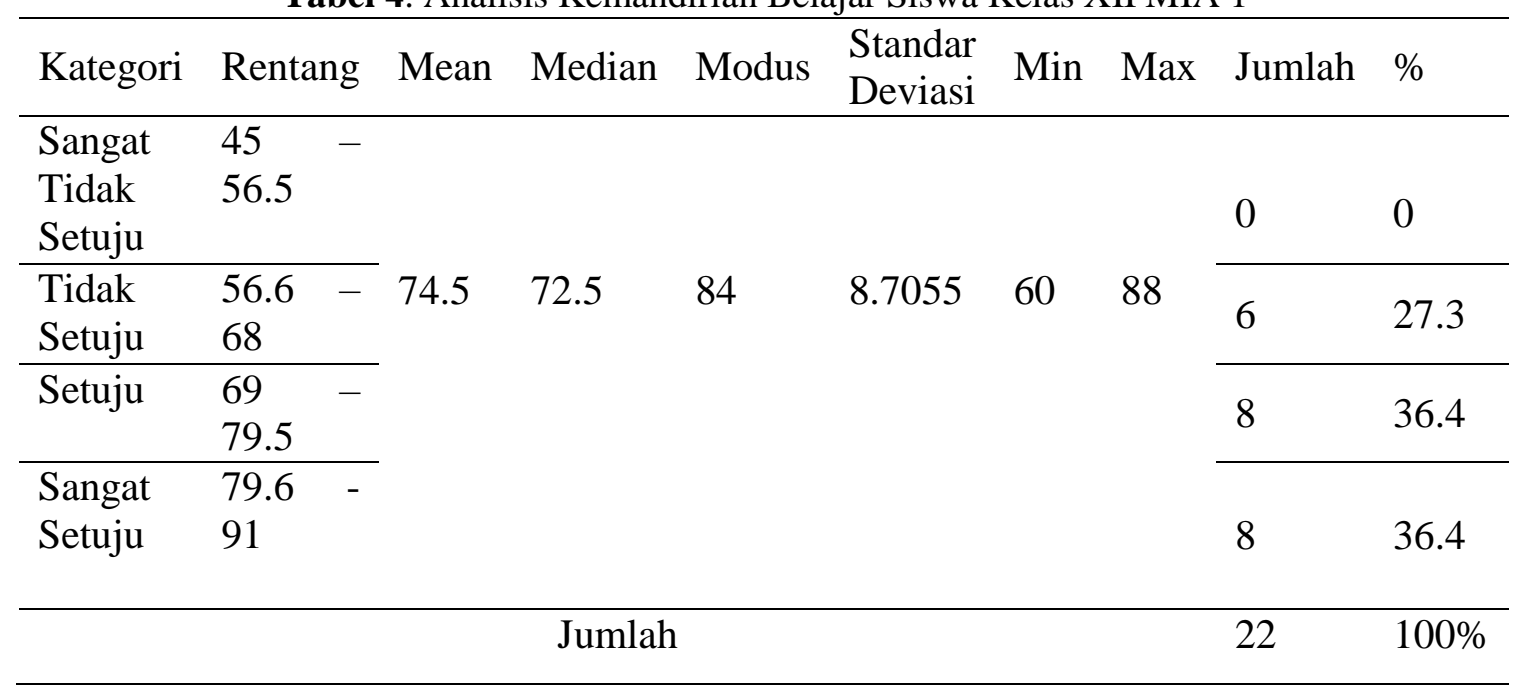

Berdasarkan hasil yang diperoleh pada tabel 4 dapat dilihat nilai-nilai statistika dari kelas XII MIA 1 yang meliputi nilai mean, median, modus, standar deviasi, nilai minimum, nilai maksimum, dan persentasi komulatif. Data yang diperoleh adalah mean sebesar 74.5; median sebesar 72.5; dan modus sebesar 84. Selain itu diperoleh juga standar deviasi sebesar 8.7055 yaitu lebih kecil dari mean. Hal ini menunjukkan bahwa nilai mean dapat digunakan sebagai representasi dari keseluruhan data, yang berarti mengindikasikan hasil yang baik. Sementara kategori sikap kemandirian belajar siswa terhadap Fisika menunjukkan: kategori sikap siswa sangat tidak setuju sebanyak $0 \%$, kategori sikap siswa tidak setuju sebanyak $27.3 \%$ (6 dari 22 siswa) atau dapat dikatakan bahwa peserta didik memiliki sikap kemandirian yang kurang baik dengan kalkulasi nilai 56.6 - 68, kategori sikap siswa setuju sebanyak $36.4 \%$ (8 dari 22 siswa) atau dapat dikatakan bahwa peserta didik memiliki sikap kemandirian yang baik dengan kalkulasi nilai 69 - 79.5, dan kategori sikap siswa sangat setuju sebanyak $36.4 \% 8$ dari 22 siswa memiliki sikap kemandirian yang sangat baik dengan kalkulasi nilai antara 79.6 - 91.

Hasil analisis deskriptif sikap kemandirian belajar pada siswa kelas XII MIA 1 MAN 1 Batang Hari menunjukan bahwa kemandirian belajar siswa memiliki kategori yang baik namun ada juga sebagian dari mereka memiliki sikap kemandirian belajar fisika yang kurang baik. Hal tersebut dikarenakan dipengaruhi oleh banyak faktor seperti faktor internal (yang berasal dari siswa sendiri) yaitu faktor fisik, psikologis dan juga faktor eksternal (yang berasal dari lingkungan) yaitu kurangnya dukungan dari orang tua dan lingkungan sekitarnya untuk belajar. Menurut Mohammad Ali dan Mohammad Asrori (2008: 118-121) ada sejumlah faktor yang mempengaruhi perkembangan kemandirian belajar, yaitu: 1) Gen atau keturunan orang tua, 2) Pola asuh orang tua. Cara orang tua mengasuh atau mendidik anak akan mempengaruhi perkembangan kemandirian anak, 3) Sistem pendidikan di sekolah, 4) Sistem kehidupan di masyarakat.

Kemandiran belajar adalah sikap yang harus dilakukan siswa pada saat 
belajar secara mandiri, siswa memiliki inisiatif sendiri sesuai dengan kebutuhan dari siswa itu sendiri. Menurut Jerrold (1994) mengemukakan bahwa keuntungan dari belajar mandiri adalah sebagai berikut: 1) Peningkatan baik dari segi jenjang belajar maupun kadar ingatan. Jumlah siswa yang gagal dalam menunjukkan kinerja yang tidak memuaskan dapat dikurangi secara nyata; 2) Memberikan kesempatan baik kepada siswa yang lamban maupun yang cepat untuk menyelesaikan pelajaran sesuai dengan tingkat kemampuan masing-masing dalam kondisi belajar yang cocok; 3) Rasa percaya diri dan tanggung jawab pribadi yang dituntut dari siswa berlanjut sebagai kebiasaan dalam kegiatan pendidikan lain, tanggung jawab atas pekerjaan dan tingkah laku pribadi; 4) Menyebabkan lebih banyak perhatian yang tercurah kepada siswa perseorangan dan memberi kesempatan yang lebih luas untuk berlangsungnya interaksi antar siswa; 5) Kegiatan dan tanggung jawab pengajar yang terlibat dalam program belajar mandiri berubah karena waktu untuk penyajian menjadi berkurang dan ia mempunyai waktu lebih banyak untuk memantau siswa dalam pertemuan kelompok dan untuk konsultasi perseorangan; 6) Memang pendekatan utama ke arah belajar mandiri mungkin tidak efisien dari segi biaya dalam jangka pendek, namun karena teknik dan beranekan sumber digunakan berulang-ulang dengan kelompok selanjutnya, biaya program dapat dikurangi secara nyata; 7) Siswa cenderung lebih menyukai metode belajar mandiri daripada metode tradisional karena sejumlah keunggulan yang dinyatakan di atas. Sehingga dapat dikatakan bahwa belajar mandiri memberikan keuntungan seperti siswa mempunyai rasa percaya diri tinggi, belajar lebih giat dan mempunyai rasa tanggung jawab.

Selanjutnya penelitian pada kelas XII MIA 2 MAN 1 Batang Hari, gambaran menyeluruh mengenai statistika dasar dari data variabel penelitian di kelas XII MIA 2 disajikan pada tabel 5 sebagai berikut. Berdasarkan hasil yang diperoleh pada tabel 5 dapat dilihat nilai-nilai statistika dari kelas XII MIA 2 yang meliputi nilai mean, median, modus, standar deviasi, nilai minimum, nilai maksimum, dan persentasi komulatif. Data yang diperoleh adalah mean sebesar 71.09; median sebesar 73; dan modus sebesar 73. Selain itu diperoleh juga standar deviasi sebesar 11.1843 yaitu lebih kecil dari mean.

Tabel 5. Analisis Kemandirian Belajar Siswa Kelas XII MIA 2

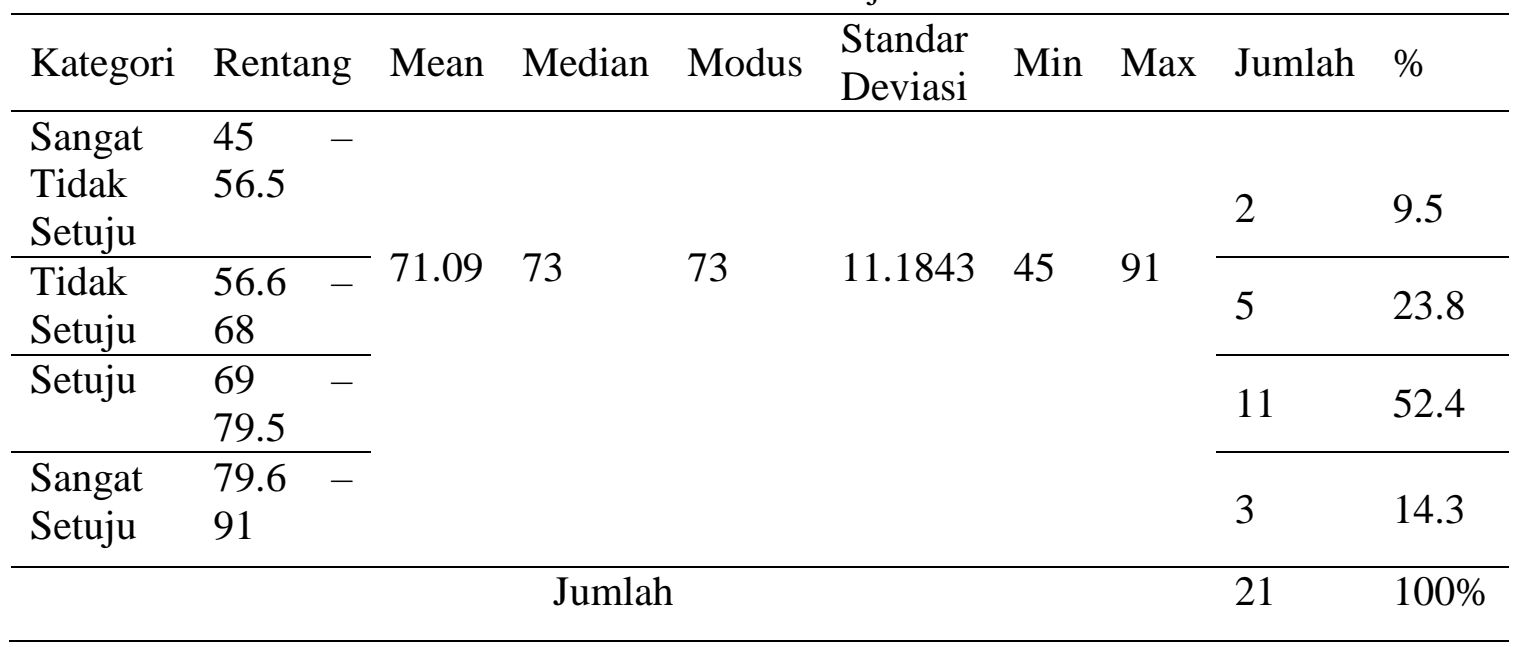


Hal ini menunjukkan bahwa nilai mean dapat digunakan sebagai representasi dari keseluruhan data, yang berarti mengindikasikan hasil yang baik. Sementara kategori sikap kemandirian belajar siswa terhadap Fisika menunjukkan: kategori sikap siswa sangat tidak setuju sebanyak 9.5 $\%$ atau 2 dari 21 siswa memiliki sikap kemandirian yang tidak baik dengan kalkulasi nilai 45 - 56.5, kategori sikap siswa tidak setuju sebanyak $23.8 \%$ (5 dari 21 siswa) atau dapat dikatakan bahwa 5 peserta didik memiliki sikap kemandirian yang kurang baik dengan kalkulasi nilai 56.6 - 68, kategori sikap siswa setuju sebanyak $54.4 \%$ (11 dari 21 siswa) atau dapat dikatakan bahwa peserta didik memiliki sikap kemandirian yang baik dengan kalkulasi nilai 69 - 79.5, dan kategori sikap siswa sangat setuju sebanyak $14.3 \%, 3$ dari 21 siswa memiliki sikap kemandirian yang sangat baik dengan kalkulasi nilai antara $79.6-91$.

Hasil analisis deskriptif sikap kemandirian belajar pada siswa kelas XII MIA 1 MAN 1 Batang Hari menunjukan bahwa kemandirian belajar siswa memiliki kategori yang baik karena kategori setuju paling banyak dipilih oleh siswa namun ada juga sebagian dari mereka memiliki sikap kemandirian belajar fisika yang kurang baik. Hal ini dikarenakan, masih ada beberapa siswa yang menganggap fisika itu sulit sehingga mereka kurang menyukai pembelajaran fisika sehingga menyebabkan kurangnya sikap kemandirian belajar pada pembelajaran fisika. Hal ini disebabkan kurangnya kemauan dari diri sendiri untuk lebih mandiri ataupun faktor eksternal misalnya dari orang tua yang masih menganggap anaknya tidak mampu melakukan suatu hal itu sendiri. Hal tersebut perlu menjadi perhatian kita semua untuk menumbuhkan semangat belajar dan kemandirian belajar siswa agar mampu menguasai materi dari pendidik. Dapat dikatakan bahwa tingkat kemandirian yang dimiliki oleh siswa berbeda- beda yaitu ada yang sangat baik, baik, kurang baik, bahkan tidak baik.

Kurangnya kemandirian dikalangan remaja berhubungan dengan kebiasaan belajar yang kurang baik yaitu tidak tahan lama dan baru belajar setelah menjelang ujian, membolos, menyontek, dan mencari bocoran soal ujian (Ali, 2008). Salah satu peran guru adalah membantu siswa dalam melatih dan membiasakan siswa berprilaku mandiri pada setiap aktivitas kegiatan pembelajaran. Untuk mengembangkan kemandirian belajar siswa maka guru hendaknya menciptakan suasana belajar yang kondusif dan menghindarkan sesuatu yang akan mengganggu belajar siswa, mendorong siswa memahami metode dan prosedur yang benar dalam menyelesaikan suatu tugas, membantu siswa mengatur waktu, menumbuhkan rasa percaya diri pada siswa mereka mampu mengerjakan tugas yang diberikan, mendorong siswa untuk mengontrol emosi dan tidak mudah panik ketika menyelesaikan tugas atau menghadapi kesulitan, serta memperlihakan kemajuan yang telah dicapai siswa (Rijal, 2015). Kemandirian belajar akan tumbuh jika siswa memiliki tingkat kesenangan yang tinggi terhadap suatu mata pelajaran yang disukainya. Kesenangan belajar dalam sains menjelaskan tentang tanggapan siswa terhadap pelajaran Fisika, yang ditunjukkan dari kesenangan peserta didik terhadap pelajaran Fisika dan seberapa keinginannya untuk belajar (Kurniawan, 2018). Siswa yang memiliki kemandirian yang baik, cenderung dapat melakukan komunikasi dengan baik, bahkan mampu memberikan gambaran nilai yang bermakna. Untuk itu sangat diperlukan sikap kemandirian dalam proses 
pembelajaran.

\section{PENUTUP}

Kemandirian belajar merupakan salah satu faktor yang menentukan keberhasilan siswa dalam belajar, sehingga sikap mandiri ini penting dimiliki oleh siapa saja yang ingin mencapai kesuksesan dalam hidupnya. Kesenangan belajar dalam sains menjelaskan tentang tanggapan siswa terhadap pelajaran Fisika, yang ditunjukkan dari kesenangan peserta didik terhadap pelajaran Fisika dan seberapa keinginannya untuk belajar. Berdasarkan hasil penelitian yang didapatkan, maka dapat disimpulkan bahwa sikap kemandirian belajar siswa pada kelas XII MIA 1 dan XII MIA 2 MAN 1 Batang Hari memiliki tingkat kemandirian belajar yang baik. Tetapi tidak semua siswa memiliki kategori baik, karena setiap individu siswa memiliki karakter yang berbeda-beda. Kemandirian belajar dapat dipengaruhi oleh faktor internal (dalam diri sendiri) dan juga faktor eksternal (dari lingkungan). Untuk meningkatkan kemandirian belajar sangat diperlukan peran guru untuk membantu siswa meningkatkan sikap kemandirian belajar dengan cara menggunakan metode dan prosedur yang benar. Selain itu orang tua juga menjadi peran penting dalam proses belajar siswa.

\section{REFERENSI}

Aini, P. N., \& Taman, A. 2012. Pengaruh Kemandirian Belajar dan Lingkungan Belajar Siswa terhadap Prestasi Belajar Akuntansi Siswa Kelas XI IPS SMA Negeri 1 Sewon Bantul Tahun Ajaran 2010/2011. Jurnal Pendidikan Akuntansi Indonesia, 10(1).

Ali, M. \& Asrori, M. 2008. Psikologi Remaja Perkembangan Peserta Didik. Bumi Aksara: Jakarta.

Astalini, A., Kurniawan, D. A., Perdana, R.,
\& Pathoni, H. 2019. Identifikasi Sikap Peserta Didik terhadap Mata Pelajaran Fisika di Sekolah Menengah Atas Negeri 5 Kota Jambi. UPEJ Unnes Physics Education Journal, 8(1), 34-43.

Babari. 2002. Relasi dengan Sesama. Elex Media Komputindo: Jakarta.

Burhan, B. 2013. Strata Perilaku Belajar Statistik Inferensial Mahasiswa Stain Sultan Qaimuddin Kendari. $A l$ Ta'dib, 6(2), 116-128.

Daeli, W. 2018. Pengaruh Fasilitas, Motivasi dan Kemandirian Belajar Terhadap Hasil Belajar Fisika Siswa Kelas XI IPA di SMA Negeri 1 Depok Tahun Ajaran 2017/2018. Skripsi. Yogyakarta.

Hidayat, W., Taufik, M., \& Gunawan. 2019. Pengaruh Model Pembelajaran Inquiry Training Berbantuan Multimedia Terhadap Penguasaan Konsep Fisika Peserta Didik. Jurnal Pendidikan Fisika dan Teknologi, 5(1), 1-6.

Holstein, H. 2000. Murid Belajar Mandiri: Situasi Belajar Mandiri dalam Pelajaran Sekolah, Remaja Karya: Bandung.

Inah, E. N. 2015. Peran Komunikasi dalam Interaksi Guru dan Siswa. AlTa'dib, 8(2), 150-167.

Iriantara, Y. 2014. Komunikasi Pembelajaran (Intraksi Komunkatif Dan Edukatif di Dalam Kelas), PT. Remaja Rosdakarya: Bandung.

Jerrold, K. E. 1994. Proses Perancangan Pengajaran, ITB: Bandung.

Kurniawan, D. A., \& Astalini, A. 2019. Evaluasi Sikap Siswa Smp Terhadap Ipa Di Kabupaten Muaro Jambi. Jurnal Ilmiah Didaktika: Media Ilmiah Pendidikan dan Pengajaran, 19(1), 124-139.

Lestari, I. 2015. Pengembangan Layanan Informasi Teknik Symbolic Model Dalam Membantu Mengembangkan Kemandirian Belajaranak Usia 
Sekolah Dasar. Jurnal Konseling GUSJIGANG, 1(1).

Nahdliyati, R., Parmin, P., \& Taufiq, M. 2016. Efektivitas Pendekatan Saintifik Dengan Model Project Based Learning Tema Ekosistem Untuk Menumbuhkan Kemandirian Belajar Siswa Smp. Unnes Science Education Journal, 5(2).

Permana, D. S., Rachmat, N., \& Ismail, Y. 2014. Potret Sikap Toleransi Beragama Siswa. Jurnal Studi AlQur'an, 10(2), 168-177.

Rijal, S., \& Bachtiar, S. 2015. Hubungan antara Sikap, Kemandirian Belajar, dan Gaya Belajar dengan Hasil Belajar Kognitif Siswa. Jurnal Bioedukatika, 3(2), 15-20.

Rusman. 2014. Model-Model Pembelajaran Mengembangkan Profesionalisme Guru. Rajawali Pres: Jakarta.

Sarah. 2019. Peningkatan Kerja Sinergis Melalui Pembelajaran Fisika Berbasis Potensi Lokal. Jurnal Pendidikan Fisika dan Teknologi, 5(1), 7-15.

Siswanto. 2016. Keterampilan Proses Sains Dan Kemandirian Belajar Siswa, Jurnal Ilmiah Penelitian dan Pembelajaran Fisika, 2(2), 10-28.

Sugiyono. 2016. Metode Penelitian Kuantitatif, Kualitatif, dan $R \& D$, Alfabeta: Bandung.

Supriyanto, A., \& Wahyudi, A. 2017. Skala karakter toleransi: konsep dan operasional aspek kedamaian, menghargai perbedaan dan kesadaran individu. Counsellia: Jurnal Bimbingan dan Konseling, 7(2), 61-70.

Taupik, Nuriah, T., \& Umasih. 2017. Pengaruh Metode Pembelajaran dan Kemandirian Belajar terhadap Sikap Siswa pada Pembelajaran Sejarah SMA Negeri 3 Karawang, Jurnal Pendidikan Sejarah, 7(2), 50-68. 